\title{
PAPIEŻ DAMAZY JAKO OBROŃCA CZYSTOŚCI WIARY* (W 1600 rocznicę śmierci)
}

Sw. Damazy /366-384/ jako papież z urzędu obowiązany był zablegać o czystość 1 ortodoksyjność chrześcijańskiej wiary. Obok wielu jego zasług wobeo powierzonogo sobie Kościoła warto sie przyjrzeć 1 lej stronte jego biskuplej dzialalności, tym bardziej, że nie została ona jeszcze dostatecznie opracowana w nowozytnej literaturze patrystycznej ${ }^{1}$.Nie pozostawiz on po sobie jakichś specjalnych traktatów polemiczno-dogmatycznych ani wielkich dạez apologetycznych ${ }^{2}$, ale przecdw współczesnym soble religljnym błęuom występował przede wszystkim na zwoływanych przez siebie synodach rzymskich, na których wspólnie z zebranyad blskupainl, obok spraw dyscyplinarnych, potęplaz herexje; wyjaśniał apostolską wiarę 1 wyrazał ja w listach synodalnych. I to właśnie dokumenty sa dla nas zasadniczym źródłom do poznania jego apologetycznoJ działalności. W naszym wyst.tpieniu starać się będzieny zobrać wszystkie jego doktrynalne antyleretyckie wypowiodzi, w których okazuje sie typowym przedstaw1c1elem $t$ kontynuatorem teologii zachodniej. Trzeba tu przypomnieć, ze przyszło mu rządzić Kościołem w okresio pełnego rozkwitu mý́l1 teologicznej, kiedy na lischodzle działali wielcy Kapadocczycy /św.Bazyl1, św.Grzegorz z Nazjanzu, św.Grzegorz z Nyssy/, a na Zachodzio św. Ambroźy

$x$ Jest to prelekcja wygłoszona podczas Sympozjum Damazjańskiego, zorganizowanego przez Miedzywydziałowy Zakład Badań nad Antykiom Chrześcijańskim KUL dnia 21 maja $1984 \mathrm{r}$. w Lublinie.

1 Mozna tu jedynie wymienié: J.Wittig, Die Friedenspolitik des Papstes Danisus I, Breslau 1912 oraz H.Al.Diptor, L'Assumptus homo patristique III, "lievue Thomiste" 63/1963/. 363-388.

2 Brak do dziś krytycznego wydania pism Damazego, odnóśnie których nie ma jednowyślności. Podręczniki/B.Altaner-B.Stuiber, Patrologle, Freiburg $1978^{8}, 354$ podaje 10 listów; J.Quasten, Patrologla, III, Roma 1978, 263-264 wymionia 9 listóvi SWP 117-9 I1stów; Clavis Patrum Latinorum, Steenbrugis 19612, 1632-1633 wyl1cza 10 listów/ wymeniaja 9-10 jego l1stów oraz 59 epigramatów, PL 13, 347-114, 1181-1196, PLS 2, 283-285, A.Ferrua, Ep1gramata Damasiana, Roma 1942 . 
z Modiolanu. Sam by jednym z plerwszych papież otwartych szeroko na kulture, co sig wyrazało w umiłowaniu piekna artystycznego ${ }^{3}$, poezj1 $1^{4}$ oraz w osobistyin studium teologicznym ${ }^{5}$. Będac z natury czlowtekiem autorytatywnym i nieugietym, przyczyniz sie w ogromnym stopniu do rozwoju nauk1 o prymacio ${ }^{6}$ do przysporzen1a najwyższego IV wieku blasku rzymskiej stolicy biskuplej, która od jego czasów zaczęto nazywac "Stollca Apostolska"7"

z Jakımi zaś wewnętrznymi niebezpleczeństwamt doktrynalnym1 papiez Damazy musiaz sie borykad, Informuje nas w duźym stopntu tzw. "Tomus Damas1", który przy pomocy 24 anatem potęp1a az 9 współczesnych herezj1: obionitów, sabelian, arian, eunomian, fotynian, pnoumatomachów, macedonian, marcelian 1 apolinarystów ${ }^{8}$. Niektóre z tych herezj1, Jak np. obionityzm, miaxy juz znaczenie historyçne, Inne zaś nadal były groźne 1 rozbljazy wewnętrznie chrześcijaństwo. Jeśl1

3 Por. J.Vives, Damasus y Filocalus, "Analecta Sacra Tarraconensia" 2/1926/483-494; A.Ferrua, Filocalo, l'amante della bella lettera, "Civiltà Cattolica" 90/1939/ 35-47.

4. Monaria, Appunti per la tradizione virgiliana nel IV socolo: Virgiliana /a cura H.Bardon/, Leiden 1971, 35-40; J.Fontaine, Nalssanoe de la poésio dans i'0ceident chrótien, Paris 1981, 111-125,

5. Por. Jego dwa listy do ów.Uleronima /PL 13,371-373/, w któryoh pro81. skynnogo ogzegote o wyjaśnienio pewnyoh zagadnioń biblijnych, oraz kilka listów/Ep 18,19,21,127/ Hieronima do Damazogo.

6 Por. S.A.Delastro, Damase I defenseur de la dootrine de la primauté de Plerre, des Salntes Ecritures ot patron des archéologues, Paris 1965; Vodonachino, Il primato nella controversia artana o nollo scista donatista, Roma 1C72 40-75; Ch.Plotri, iloma Christiana. Lecherches sur l'Eglise de liome, son organisation, sa politique, on ldéologie de Miltiade à Sixte III $/ 311-440 /$, t.1. Home 1976, 824,844-849.

7 Por. Ep1stola ad Orientales, PL 13, 370-371: "Quod vestra char1tas dobitam oedi apostolicao roverentiam tribuit .............. Itaque quid est our abdioationen Timothel a mo rursus requirat1s, qui et las hic Judicio sedis apostolicae... abdicatus est una cum magistro suo Apollinare".

8 PL 13, 358-361. 
dołaczymy do nich istnlejice w tym czasie schizny, jak sporodowana przez jego rywala antypapieza schizma Ursyna, ciagle jeszcze zyw i działaj fcy nawet w izymie donatysicl i lucyferianie, w Antiochil scinizma melecjańska oraz pojawiający sie wisispanil pryscylianio, to trzeba powledziec, ze rzłdy tego papleża wcale nie były latwe. Sam bolał nad tyı, ze wielu jego współbraci w biskupstwio dla błahych niokiedy powodóv, a nawet dla przypodobania siô innyin, zmienialo tradycje ojcór 1 popadało whorezje ${ }^{9}$.

Spośród wyzej wyinienionych horezji dwio były za pontyeikatu Damazego szczególnie groźne: nadal mocny mimo nicojekiego potępienla 1 wewnetrznego rozbicia arianizm 1 zwiazzany $z$ nim macodonianizm oraz przybierajłcy na sile, szczególnie na irschodzio, apo11 naryzm.

\section{Artantzm 1 macectontantzm}

Arıanizm, jals wieny, uczył, że chrystus nie jest prawdziwyi Bogien równyli Bogu ojcu, alo jest Bogloin drugrorzęinym, 8tiorzonym z niczogo przez Ojca. Nie jest tez Bogiem wiecznym, alo by czas

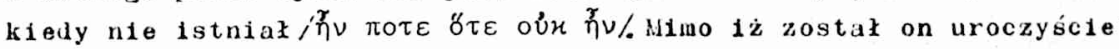
potepiony na soborze w Nicei w $325 \mathrm{r}$. poprzez anatery 1 specjalne wyznauie wlary podkreślajace, że Syn Boży jest równy 1 współistotny $0 j c u / \delta_{1} 00 v \sigma \cos \tau \tilde{\omega} \Pi \alpha \tau \rho l /$ to miat on nadal wielu zwolenników, szczególnie na Wscirodzie. Za czasów Danazogo miał on jodnak juz nieco inny charakter niz pierwotnie 1 w nowożtnej literaturze patrystycznej nazywany jest niekiedy neoarianizmen, który podzlelony by $ł$ na trzy zasadnicze grupy ${ }^{10}$, wywodzace swo nazwy od kluczowych dla nich

9 Por. Canones Synodi comanorum ad Gallos ep1scopos 2, P'L 13, 1182: "Scimus, fratres charissimi, laltos eplscopos per d1versas ecclesias ad falsam pessimam nominis sai humana prasumptione patruin traditionoin mutare properasse, atque por hanc causi in tonebras haerosis cocidisse, dum glorian hominum delectantur potius, quan Dei priemia habere perquirero".

10 Na tomat arlanizmu jost bardzo bogata bibliograpla. La ostalnia klasycent pozycje na ton temat nożna uwazać: M.Simonotti, La cr1si ariana nel IV secolo, wena 1975; cer J.1..Szyaus laik, istíp do: dureíiusz dugustyn, O Trójcy Śrigtej, Pun 25, Posnan 1962, 11-17; J.janialou - H.J.Marrou, Nouvelle histolro de l. Égise, I; Des orlgines à lirésoiro lo Grand, l'aria 1963, trum. M.'Tarnowska /ilistoria kosciola, I, Warszawa 1984/, 202-203. 


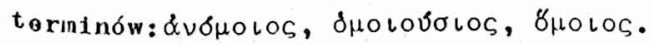

Grupa pierwsza to a $\mathrm{n}$ o m o $\mathrm{j}$ c $\mathrm{z}$ y $\mathrm{c} y$, nazywant równiez od swych przywódców aecjanara1, ounonianani lub oudoksjanami. Byli to najbardziej radykalni 1 nieustępliwi arianie, którzy twierdzili, że Syn jest całkowlcio róźny i niepodobny/\&ubpolos/ do Ojca, jest tylko stworzoniem o zupełnie odmiennoj suistancji niż ojciec. Ich przywódcaul byl1 bp Antioch11 Aocjusz $/+366 /$, bp Kyziku Eunomiusz /+394/ oraz patryjarcha konstantynopolitansisi Ludoksjusz / +370/. W oparciu o silnz poimację filozoficzn.k, szczególnie arystotelesowska,oraz o doskonała argumentacje dialektyczną uważall, że potrafia "zgłębić" nawot najglebsze tajniki natury boskiej. Utoźsamiajazc is-

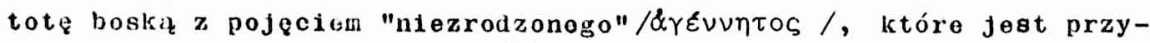
miotem tylko ojca, twierdzili, że Syn nie może być Boglea, bo jest zrodzony 1 ma zupołnio inná suistancje niż ofciec, z którym w żaden sposób nie noże być współistotny. Grupa ta powstała około $350 \mathrm{r}$, osicisneza swe najwyzsze znaczenie na synodzie w sirmium $/ 357 \mathrm{r} . /$. gdzie zabrontono określania Syna Bożego terminani: Spoovớc i drolovolos.

Gripa druga zwana $h$ o m e $u$ z $j$ a $n$ a $i$ lub semiarianaIn 1, gromadztła slę wokół Bazylego z Anoyry /+364/, który chcąc uniknać niepotrzebnych dyskusji zwiazzanych z terminem nicejskim

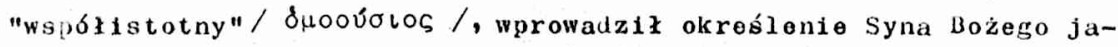
ko "podobnezo we wszystkim", a przede wszystkim w swej istocie do

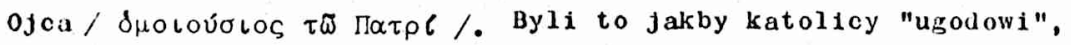
potepiajłcy zdecydowanio anomejczyków. Ich formułe wiary podpisa poprzednik Damazego papiez Liberiusz, a do najwigkszego znaczenia doszli w $359 \mathrm{r}$. na synodach w Mimini 1 Seleucji. W grupie homeuzjan pojawiza sie okolo $360 \mathrm{r}$. herezja p n o u a t o m a c hów, inaczej duchoburców lub macedonian, odmawiajacych buchow 1 swięteolu bóstwa gloszic, zo jost on sługa 1 stworzeniem ojca, nizszya od Nlego 1 calkowicle mu podporzadkowanya. Zwolennikiom tej herezji "I jej poczatków byl takze patriarcha konstantynopolitariski Macedontusz /36.1/, od ktirogo nazywano j.z równiez lacedontanizsien ${ }^{11}$. Błąd

11 Nazwa "macodonian" wystepujo po raz plerwszy u bydy ma Sloposo, Do Trinitate II, 10, P's 39, 633; cfr takzo pseudoatanazjanski Dialog przeciw Mucedonduszow1, PG 28, 1291-1337. 
ton potepiono najpierw za staraniow św. Atanazegro na synodzio aloksandryjskim is 362 roku $^{12}$, a następnio za czasów Damazego na Soborze Konstantynopolitańskina w 381 roku.

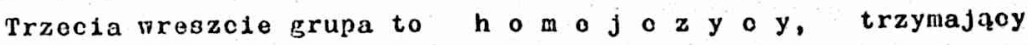
sie blizej niookreślonej formuły, ze "Syn Bozy jest według Pisma św.

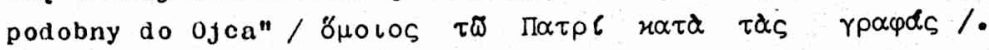
Ich przywódca był najplerw Euzebiusz z Cezare1 $/+339 /$, a później jogo następca Akacjusz $/+366 /$. I ta właśnie forma wiary stała sie od synodu konstantynopolitanskiego w $360 \mathrm{r}$. na dłuzszy czas w Cosarstwie Rzymskin wyznaniem nazywanym arianizmem. "Jest to, jak pisze J.Daniélou, waźny akt, bo skończył się okres wypracowywania doktryny: Credo zwolenników "homolos" procyzuje to, co moźnaby nazwaó arianizmem historycznym, odtąd będą go takim wyznawać wspólnoty i ludy wrogie ortodoksji katolickioj 1 Symbolowi Nicejskiemu"13. Problem arianızmu inaczej jednak wyglądał w chrześcijaństwie zachodnim, a inaczej w chrześcijaństwie wschodnim. Zachód za czasów Damazego wyznaval poza nielicznymi miejscami wiare nicejska, Wschód natomiast wewnętrznie skłócony usiłował wszelkimi sposobam1 zastapic formułe nicejska inna definjoja wiary 1 reprezentorany by w ogromej większosci przez homejczykow, a nicejczyków oskarzak czqsto o sabelianizm. Wazna role odgrywall tu równioz rzymscy cosarze. U 1le na Zachodzie cesarze wspócześn1 Damazemu, Jak Walentynian I /364-375/ 1 Gracjan /375-383/; odnos1l1 sie do ohrześc1janstiva obojętnie lub popierali wyznanie nicejskie, to waadcy $\mathbb{F s c h o d u , ~}$ jak np. Vialens /364-378/ opowiadali sle zdecydoranie za ariantzmem lub hoinejczykami. Damazy nierzadko w swej działalności antyheretyokiej korzystal z pomocy cesarskiej.

\section{a/ Antyarlańska działalność Danazego na Zachodzio}

Zachód niemal w całośc1 wyznawał wlare nicojska,poteplajac zatwiordzona na synodzie wimini 359 r. Formułe homeuzjan.Wyjatek stanowiła tu Iliria, która od czasu wygnania w te strony Ariusza, na dłuz-

12 Tomus ad Antiochonos 3, PG 26, 800A.

13 J.Daniólou - H.J.harrou, Nouvella histoiro de l'Egliso, dz.cýt. 205. 
szy okros stata siq bastionem arianizmu ${ }^{14}$. Mimo kilkakrotnogo foralalnego potepienia synodalnego, nadal tu działali ariariscy biskupi, jak: Ursacjusz z Singidunum /+371, dziś Belgrad/, a potom jego nastepca Sekundianus, Walens z Nursy /+378, dziś Osijek/, Palladiusz $z$ Latiaria, Auksencjusz z Mediolanu /355-375/, Germiniusz z Sirmium, w Kartaginie zwolennik wiary z lifmini bp liestitutus. Danazy zaraz na poczatku swego ponty $i$ katu, prawdopodobnie juz na piorwszym zwołanym przez sieblo w $368 \mathrm{r}$. synodzle rzyms'sim, potepił ariańskich biskupów z Iliri1 Ursacjusza 1 Vialensa ${ }^{15}$. Nie zachowała sia wprawdzie z teģo synodu zadna jego formalna wypowiedź, ale wiemy o niej z listu synodalnogro św.Atanazego "Ad Afros", który cieszył się, ż Damazy przez ten akt chciał "ratować" jedność Kościoła katolickiogo ${ }^{16}$; dziwlz sie jednak, ze nio poteptono jeszcze 1 nie usunięto z Kościoła Auksencjusza z Mediolanu ${ }^{17}$. Usunięcio jednat 1 potâpienie tego wpływowego arlanina z Mediolanu było stosunkowo trudne, bo złozył on w $364 \mathrm{r}$. dwuznaczne wyznanie wiary wobec Walentyniana $I$, który, mimo protestów Hilarego z Poitiers ${ }^{18}$, uwaźa go za prawowier-

140 arianizmio w Ilirij por. Moseslin, Les Arions d'occident /335-430/, Paris 1967, 59-134.

15 Na 368 r. zwołanla tego synodu wskazuja: J.Wittig, Dio Friedenspolitik des Papstes Damasus I, dz.cyt. 76; J.Zeliler, Les originos chrétiennes dans les provinces danubiennes de l'Empire roma1n, Paris 1918, ${ }^{\circ} \mathrm{K} .2$; E. Gaspar, Geschichte des Papstums, Bd 1, Tubingen 1930, 593; V. Mionachino, Il primato nella controversia ariana, dz.cyt. 44; P.P.Joannou, Die Ostkirche und dio Cathedra Petri im 4. Jahrhundert, Stuttgart 1972, 160.

16 Athanasius, Ep. ad Afros 10, 1045D: "Dziequjemy jego Poboznosci /naszemu Damazemu/ oraz tym, którzy przybyli do vielkiego niasta kzymu, zo ryrzuciwszy Ursacjusza, Walensa 1 ich zwolenn1kó, uratowali Jednomyślnosć Kosciota katollcklogo".

17 Tamze 1045CD: "Tym powodowani, zo mieliśny okazje się zgromadzić, wyslaliśmy równió do niszogo ukochanogo Danazogo bisliupa wielkiogo leymu list o Auksoncjuszu, który nawlalnzz liościołom modiolaxiskim; o jego czynach jużesmy, go powiadamiali, zo nio tylko jost zwolonnikion horozji ariaúskioj, alo takż winnym wielu wystepków, których sie dopuścil z Grzogorzem wapólnikiem swej bezboznob́ci. Dziwimy sie, dlaczogo joszpzo nie zostaz złozony z urzedu 1 wyricony z ifoscioła"; por. P.P.Joannou, Dio Ostifrche und dio Catiodra Petri, dz.cyt. 161-165.

18 Por. Hilarius Pictaviensis, Advorsus duxontiun 7, PL 10,613: "Doum verum Christum et unius cual Patre divinitatis ot sub- 
negro. Był on juz wprawdice wyklinany na synodici w ilimint w $359 \mathrm{r}$. oraz na synolzie w Paryzu w $360 \mathrm{r}$., alo nadal pozostawat na swej stolicy biskupiej. Być moze pod naciskiew ltanazogo 1 zaisrozonych 1liryjsciri nlobezpieczeńs twoil biskupów Gal11 1 pótnocnej Itali1, zwotal Dasazy $15 \times 368$ r. ${ }^{19} 93$ biskupón na synod rzymski, który formalnio potepil Auksenejusza wraz z Walensea 1 Ursacjuszem 20

1 skierował do bistsupów Ilirii list synodalny "Confidimus quidevi"

- charakterzo doktrynalnym. oto pierwaza zachowana antyariańakin wy-

powiedic Damazogo:

"Denique suxentiuin Micd 101 anonsor hac praocipue causa danmatum csse priescribunt. Par est igitur, universos magistros le;s per orbem kowanum paria de lobo sentire, noc diversis magisterits fidem dominican violare. Nan cum

stantiae colfitetux"; tamże 14, 617: "Jesum Cirristum ante onnta saecula et ante omne principiur natum ex Patro Deum verua Filituil ex vero Deo Patre propessus ost"; por. L.Duciesne, ilstoire ancienne lo l'Elise, t.2, Paris 1908, 358.

19 Sati t: proponuje P.P.Joannou, Die Ostkirche und dic Cathedra putil, dzecyt. 163. Viśról historykór nie ma jedrak co do nioj a:ouly. M.dale /Danasus, Bischof von lom, Borlin 1882/. V.Mona:ilino/ri pismito nelia controyersia ariana, dz.cyt. 41-45/, if.J.ikefele - i.Lecierq/ilistoire dos conciles, i.2, Paris 1908/ . . . iller /Les ori rines chrétiennos, dz.cyt./ prpponuja dat? B.jo; i. intifiol /La siège apostoliquo 359-451. Par is 1924/

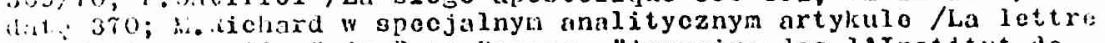
"Conifidisus quidea" du Pape Damase, "sinnuairo dos loInstitut do pililolosie et d'hlstoire orientales ot slaves" 11/1951/323-340, Bruxolles' rok 371; F.Cavaliera /Le schisno d'Antioche, Paris

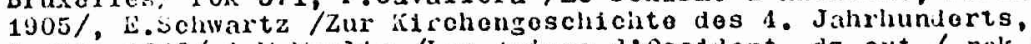
Borlin 1960/ 1 M.Meslin /Los lriens d occtuent, dz.cyt./ rok 372 ; Ch.pietri, :ioma Christ-ana, dz.cyt. 733/ dat 371 lub 372 .

20 Por. itlianasius, Ep. ad Epictetum 1, PG 26, 1052 A: "Dlacero w tym czasto różo synody zwolywano w Galii, iliszpinit 1 wel-

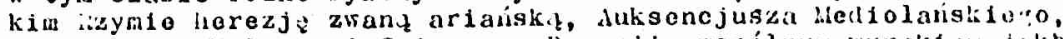
Ursacjusza, lialousa 1 Gajusza z Panonil, wspólnya wyrokion liaby za natchiculou to:so samejo Ducha vyklaty". 
dudun haereticorui virus, ut nunc iterua coepit obrepere, ac praocipuo arianorun blasphenta pullulare coepissot, aajores nostri CCCXVIII opiscopi, atque ex urbe sanctissind episcont urbis tonae directi, apud Nicaoam confocto concilio, hunc murum adversus arma diabolica statuerunt, atque hoc antifoto mortalia poeula propulsarunt, ut patrem, Filium, Spiritumque sanctum unius deitatis, unius figurae, unius crelero oporteret substantiae, contra sentientem alienun a nostro consortio judicantes. Quam deendtionew salutarein postea alis tractatibus quidam pervertero violare tentaverunt. Sed ot in ilso cxorlio ab ilsderil ipsis, qui hoc apud Ariminum rotractare cogebantur, emendatum hactenus ost, ut subreptum sibi alia disputationem faterontur, idcirco quod non intellexissent Patrum sententiam apud Nicaoam Pornatam esse contrarium. Neque onim praejudicium aliquod nasci potuit ex numero eorum, qui apud Ariminum convonerunt: cum constet, neque lomanum episcopui, culus ante omes fuit expetenda sententia, neque Vicontiua, qui tot annos sacerdotiue illibate sorvavit, nequo alios huiusmodi statutis consensum aligue commolasse: cum praesortim, ut diximu, liden ipsi, qui per impressionoli succubulsse videbantur, idiem consilio wellore d1splicere sibl Puerint protestati. Unde aivertit sincertias vestra nanc solan ridea, quae apul Niciean Apostolorum aluctoritate rundatil est, perpetua rixistate osso retinendan; hac nobiscum Orientaleg qux se catholicos recognoscunt, occlaentalesque gloriari"21.

Z wyzej przytoczonogo tekstu wynika, żo Damazy sankcjonował wi swy 11ście trzy zasadnicze fakty: uznanie 1 potwierdzenio jako jedynoj prawdziwoj wiary, stanowlacej podstawe wszelkioj conuunio ecclosiastica Symbolu Nicejskjego, który nazywa "murem" i "zbawienną dofiniojiz" potępionio Auksenejusza oraz uniewazniento decyzji synodu z ildini w 359 r., bo njo było na nie zgody biskupa lizymu, and Jogo statutón czy logata Wincentego. Jeśl1 chodzi o potepienio suksencjusza, to jest ono bardzo ostrożno 1 nio wyraza pełnej okskomuniki, alo jost ono tylko potwierdzeniem dawnych potegioń, by nowymi locyzjani nio draznić cesarza. Nic tez dziwnogo, zo potupiente to nie oslagneto wielklogo skutku, bo duksoncjusz, podobnto jak 1 Ursacjusz, Halons 1 Goxinfiusz, pozostali na sivych sto-

21 PL 13, 348-349. Maray łachiskit 1 grock wersjy tego 11 stu. Przytoczony fragmont pochodzl o odplsu lacinskiego orysinatu przostatic;o w $372 r$. na lisciód. Grecka vorsja tokstu przosianot;o do biskupuw Ilirii, Mzokazania jost przuz jozomana/il.E. VI, 23, GCS 50, 260, thun. Kiaikowsid, 398-400/ 1 Toolorota il.L. II, 22, iCS 19, 147\%. Ponowny laciusli praektal z greckiogo 
11 ach biskupich aź do śmiorc1.

W definicji doktrynalnoj: "ut Patrom, Filium, Spiritumquo Sanctum unius deitatis, unius figurae, unius credere oporteret substantiae" podkroślona jest całkowita równość 1 waṕfłistotność trzech Osób Boskich, wyrażona językiem teologi1 zacholniej. Sana formuła nawizzuje do doksologil trynitarnoj, w której połozony jest nacisk na teologie Ducha Swietogo. Fyrazenie "una de1tas" wykluczajace wyróżnianie pod względem wielkości bóstwa którejó 0soby Trójcy Sీw., nawizzuje do subtelnych rozróznien teologicznego słownictwa homejczyków, przeciwstawiajacych "dealitas fili1" de1tat1 Patris"22. Wyrażenio "una figura", zapożyczone z Jezyka biblijnego /Hbr 1,3/, podkreśla pełne podobierístwo między trzema osobami Boskimi. Wreszcio określenie "una substantia", zamiast wochodniogo wyrażenia "una ousia", przelozonego przoz Teodoreta "una hypgtasio", a przez Kasjodora "una essentia sive substantia", podkreśla pełna współistotność trzech Osób Bosxich.

Na wyżoj przytoczonym orzeczeniu kończa slą zachowane wypowiedzi Damazego przociw arianizmow zachodniemu. Do jogo wyntezozenta w Ilfril 1 północnej Italil przyczynił sie w duzym stopniu św.Ambrozy z Mediolanu, który nie tylko zręcznio w 376 lub $377 \mathrm{r}$. miejsoo zmailego Germiniusza osadzit na metropolitalnej stoliey w Sirmium ortodoksyjnego hiskupa Anemiusza ${ }^{23}$, ale wspólnie z cosarzem Gracjanem doprowadzit do zwolanla w $381 \mathrm{r}$. synode w Akwile1, gdzio zebrant b1akupl północnoj Itali1 wykląl ostatn1c'. zwolenników arianizmu w Il1ril: Palladiusza z Ratiaril 1 Sekundianusa $z$ Singldunum, cesarz zaś skazal

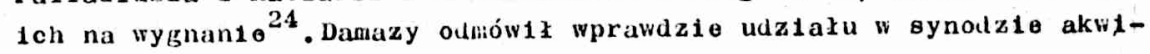

tekstu przekazał Kasjodor /ifistoria tripartita V, 29, CSEL 71, 257-258/; Komentarz: P.P.Joannou, Die Ostk1rcho und dio Cathodra Petri, dz.cyt.,162-165; Ch.pietri, loma Christiana, dz.cyt., T33736, 777-782; V. Nonachino, Il primato nella controvorsia ariana. dz.cyt., 44-47.

22 Por. to rozróznienia u Palladiusza, Impassibilis Vorbum Deus, Prs. XII / Aleslin, Les Ariens d'Occident, dz.cyt., 317/; "doltas" natomast nalozy do slownictwa toologicznogo Euzebiusza z Vorcelli, por. De Trinitate, 1,$9 ; 58$, CC 9,5 i 16 .

23 Por. Paulinus, Vita Aubrosil Il, tlum. J.bogaszowlcz/Siv. Ambrozy, o wielze, Harsaawa 1970/ 229-229; J.Zeilier, Les origines Chrétionnes, dz.cyt., 145 1 309; Ch.Pletri, coma Chistiana, da.cyt., 782.

24 J.Srutwa, Synod akwilojski 381 - zachodni olpowiodnik soboru konotantyopolskiogo I, "Vox Patrum" 3/1983/ 190-199. 
lejskim zo względu na spowodowane przez zwolenników Ursynusa zanieszk1 w lizyinte 1 niespodziewante sie po nim więszych owoców ${ }^{25}$, ale przeskaz tam trzy swoje listy, odczytane wobec zebranych przez samego Ambrozego ${ }^{26}$. N1e zaohowały sie one wprawdzie, ale ich treść możemy odczytać z postanowień przekazanych w synodykach akwilejskich ${ }^{27}$. Wydajo s1e, zo drugi spośród nich zawieraz potępiente Palladiusza 1 Sekundlana, bo protestowal1 on1 w "Dissertatio Maximini" przeciw niemu, Jako głównemu sprawcy tch wyklęc1a ${ }^{28}$. Moźna więc dopuśclé 1 taka hipoteze, ze zebrani na synodzie blskupi potwierdzill tylko nadesłane przez Damazego potepienie przywódców ariańskich.

\section{b/ Antyariańska działalnośd Damazego na Wschodzie}

Trudniejeze zadanie zwalczania arianizmu miał papiez Damazy na Wrchodz10, gdzio herezja była o wiele mocniejsza 1 cieszyła sie poparciem cesarza Walensa, chrześoijaństwo zaś bardziej skłócone: wiele stol10 b1skuploh obsadzonych było przez homejczyków a nawet przez anomejczyków. Typowym przykładem wewnętrznego rozbicia na Wechodz1e był Kośc1́́ł w Ant1och11, gdz10 społeczność chrześc1jańska liczyla az pię́ rywalizujących ze soba wspólnot. Nalezeli do nioh najplerw niezbyt lioznl, alo cleszaoy sie poparciem Damazego n 1 - $J$ c z y, przeciwni wszelkim ustepstwom, skupieni wo-

25 Por. L.Duchesne, Histoire ancienne de l'Eglise, dz.cyt. 473.

26 Por. Dissertatio Maximini 122, PLS 1,722: "Praeterea cum nec tu Ambros judex esses... dio nobis, qua auctoritate et1am a Damaso missas... tres opistulas tibi ipse quoque per temetipsum rocitandas duxist1, oum utiquo etsi tu judicis personam haberes, potuisses non por temetipsum epistolas legere, no judicis auctoritatem off 1010 de10eros ministri"?

27 P.P.Joannou, D1e 0stkirohe und die Cathedra Petri, dz.cyt. 258-260.

28 Dissertatio Maximini 123, PLS 1,722: "Sed forte fides beatissim1 Potri praerogatibiam vestra, familiarium ot clientulorum, adsensiono vindicat sibi, cur non et ipse advertit ot vos intoligitis, Petri sodeli ound bus episcopis et aequalom osse et communem". 
kół konsokrowanego w 362 r. przez Lucyferiusza z Calaris b1skupa Paulina. Obok nich najliczniejsza chyba grups stanowll1 hom 0 u z ja n 10 , tworzacy neoortodoksyjne stronnictiro wierzacych poprawnie, ale odrzucajacy formułe nicejska, 1 w zwizzku z tym oskarżani przez pioriszych o arlanizm, skupieni wokóx Jelocjusza, praw 1cowego wyznawcy "holiolos". Trzocia wspólnota byll radykalni a $n$ o m e j c z y y skupient wokóz bezpoéredniego ucznia Ariusza, biskupa Euzojusza. Czwartá wspólnote tworzyła działajłca od $362 \mathrm{r}$. oriontacja z 01 o n n 1 k 6 w A p 01 i a $r$ eg o z Laodycel, postadajaca od $376 / 77$ wlasnego biskupa Witalisa. I piazta wreszcio grupa byli ma codon 1 a 1 e kwestionujący bóstivo Ducha Siriętogo.

Traged1e wewnętrznego rozdarcia 1 skłóconia chrześcijaństwa na Wschodzie przezywal najbardziej biskup Cezarei Kapadockiej św. Bazy 11, który popierająo homeuzjáskie stronniotwo Nelecjusza, wielokrotnie od $371 \mathrm{r}$. sam lub w Imleniu biskupów Wschodu prosiz - ponoc 1 przysłanie delegacj1 Zachodu, która by rozeznała sytuacj\& na miojscu, poprzez listy kierowane do Atanazego lub papieza. Episkopat iischodu obok rozdarcia znosiz do r. 377 ciezar przésladowán ze strony cesarza lialensa 1 oczekiwal duchowego wsparcia od biskupów zachodnich. Damazy jednak nie potrafil zrozumiec tych apeli i popełulł przy tyon wiole błędón taktycznych: popierając uparcie nicojskie stronnictwo Paulina, odpowiadal na nie jedynie listami, "których bez zadnych ustępstw personalnych domagal 19 autorytatywnie 1 uporczywie, bez wnikania w zanikłanz problematyke Hisciodu, podpisania Syinbolu Nicejskiego. Nie begdziemy w tyomiejscu omawiać relacji Bazyl1 - Damazy, bo ten obszerny problem jest juz obficie opracowany wowozytnej literaturze patryatycznoj ${ }^{29}$. Dopiero

29 Por. R. Richard, Saint basile et la mission du diacre Sabina, "Analecta Bollandiana". 67/1949/178-202; d. de Menuieta, Dawaso, Athanase, Pierre, déloce et basilo. Les rapports dos comounion occlésiastique entre l'Bgliso de Rome, d'Alexandrio, d'Antioche ot de Césarée de Cappadoce/370-379/, w: Loglise et les Églises, t.1, Chevetogne 1054, 261-251; N.Corneanu, Les efforts do Salnt Basile pour l'unité de l'Église, "Verbun Caro" 23/1969/10,43-67; J.Taylor, St.Basil the Great and Pope Damasus I, "Downside Keview" 91/1973/166-203. 
po śnierci Walensa /378/ 1 zelżeniu prześladowán doszło w $379 \mathrm{r}$. na synodzie w Antiochil do przyjęcia przez biskupóv Wschodu, a wśród nich przez wszystkich inspiratorów neoortodoksjl, damazjańskiego wyznanla wiary; wówczas to doplero Wschód stanąl obok Zachodu w Jednym szeregu do walki z arianizmer.

Z ówczesnej antyheretyckiej działalności Danazego omówimy teraz wypowiedzi skierowane przeciw arianom i pneumatomachom, zgrupowane wokóz dwóch skierowanych na Wschód listów synodalnych.

Pierisza zich zawarta jest w zachowanym eragmencie dogmatycznym "Ba gratian30, stanowiacym wyjatek z listu synodalnego/pocz. $376 \mathrm{r} . /$, który był odpowiedzia Damazego na listy Melecjusza, Bazylego 1 biskupów Wachodu ${ }^{31}$, przywiezione pod koniec 375 r. przez Doroteusza I Sanktissima. Biskupi Wschodu, zagrozeni ariańskim niebezpieozeństwem, zuracają się z listami na Zachód prosząo o pomoc w ich trudnej sytuacj1. Zachowany fragment synodalnego listu Damazego zawiera soble trynitarne wyznanie wiary przeciwstawiajace ortodoksyjnz nauke błędom arian, pneumatomachów, apolinarystów, sabelian, eunomian, marcelian 1 fotynian, ale bez wymleniauia ich nazw oraz podane autorytatywnie papieskie warunki konieczne do uzyskania communio ecclesiastica $z$ lzymem. A oto interesujaca nas wypowiedź Damazego:

". omnes uno ore unius virtutis, unius majestatis, unius
divinitatis, unius usiae dicimus divinitatem: ita ut
inseperabilem potestatem, tres tamen asseramus esse perso-
nas, nec redire in se aut winui, ut plerique blasphemant,
sed semper manere; nec potentiae gradus quosdam ortusque
tempora disparata; nec prolativum, ut generationem ei
demas; nec lmperfectum, ut ad personam aut Patris natura,
aut divinitatis el plenitudo defuerit; nec dissimilem
opere Filium, nec dissimilempotestate, aut per universa
dissimilem: nec subsistere aliunde, sed de Deo naium, nec

30 PL 13, 350-352, P.P.Joannou, Die Ostk1rche und die Cathedra Petri, dz.cyt., 207-211; Ch.Pietri, Roma Christiana, dz.oyt., 829-831; V.Monachino, Il primato nella controversia ariana, dz.cyt., 51-52 proponuje wiosne 377.

31 Jest to 243 list Bazylego do biskupów Ital11 1 Gal11, PG 32 , 901-912, 2 zuts. W.Krzyzanials/Sw.Bazyl1 Nitelk1, Listy, Farszawa 1972 /298-303. 
Palsun de Deo vero, sed Deum verum de Deo vero esse generatum, lumen verum de vero lumine; neo minutum aut diversum putetur: quod unigenitus habet splendorem lucis aeternae quia naturae ordine neque sine splendore lumen; neque splendor potest esse sine lumine: lmaginem quoque Patris, ut eum, qui viderit, viderit et Patrem. Eumdem redemptionis nostrae gratia processisse de Virgine; ut perfectus homo pro perfecto, qui peccaverat homine nasceretur. Ergo, Pratres, asseramus De1 Filium ot perfectum hominem suscepisse. Spiritum quoque sanctum increatum atque unius majestatis, unius usiae, unius virtutis cum Deo Patre et Domino nostro Jesu Christo fateamur. Neque enim creaturae dignus injuria est, qui emissus est ut crearet, sicut propheta sanctus astruxit dicens: "Emitte Spiritum tuum et creabuntur"32.

W przytoczonyin Pragmencie latwo rozpoznajemy styl 1 jezyk toologiczny Damazego, znajdujzzcego sie pod wyraźny wpływem nauk1 tryn1tarnej Euzebiusza z Vercelli: "unius virtutis, unius majestat1s, unius divinitatis, unius usiae dicimus divinitatem". Na sohemacie doksologil trynitarnoj, zaczerpnietej z Biblil lub liturgil, Damazy z cała siła podkreśla równość mooy, majestatu, bóstwa, 1stoty 1 wladzy wszystkich trzech 0s6b Boskich. Przez wyrazenie "unius virtutis" chcial zaperne Damazy, podobnie Jak Euzebiusz z Vercel1133, wykluczyć wszelki rozdźwięk woll 1 działania trzech Osób Boskich. nówniez określenie "unius majestatis", będace ekwivalentem biblijnego "gloria" $/ 1$ Kor $2,2 /$, spotykane jest w Jezyku trynitarnyu takich autorów zachodnich jak Mariusz Wiktoryn, Euzobiusz z Vercell1, 1 Ambrozy z Mediolanu ${ }^{34}$. Przez uzycie grecklego kluczowego terminu "usia", znanego Juz Hilareau 1 Euzebiuszowi z Vercell1, chclał zapewne Damazy usuną́ wszelka dwuznaczność wiazaca sle z uzywanym częéciej na Zachodzie terminem "substantia". Obok tych ogólnych antyariańskich stwierdzeń, papiez przeciwstawia sie ezczególnie odia-

PL 13, 351 AB.

33 Por. Eusebius Vercellensis, De Trinitate I, 58, CC 9, 16: "Est multiplex praesaga sapientia Patris et Filif et Spiritus Sancti et est una virtus sive forna magnitudinis sive una maiestas 81 ve una claritas".

34 Uilarius, De Trintiate IV, 4, CC 62, 103: "unius quoque malestatis Patrot Filiumque dooeamus"; IV, 6, CC 62, 104-106; Eusebius, De Trinitate V, 37, VII, 31, CC 9,74,99; I, 58, CC 9, 16; Mariug Victorinus, Ad Candidum 31, SCh 68,172; Ambrosius, De fide, 3 , $13,103, P L 16,635$. 
mowi tej herezj1, Jakim jest anomeizm Eunomiusza: "nec dissimilem opere Filium, nec diseimilea potestate, aut per universa dissimilem". Iduc dalej za schematern wyznania wiary, papiez po potepientu ariańskich błędów przeolw Synowi, przeciwstawla sie dalej błędom pneumatomachów, odnosząc do Ducha Swiętego niemal tę samą terminologle, Jaki stosomal odnośnie drugiej 0soby Boskiej: "Spiritum quoque Sanctum increatum atque unius majestat1s, unius usiae, unius virtutis cum Deo Patre ot Domino nostro Jesu Christo fateamur". Warto podkreślić, de po raz pierwszy w teologii zachodniej Duch áw. jest tu nazwany "increatus"35. Trudno jest ustalic, czy na tego rodzaju sformułowania o Duciqu Świętym wpłynęła u Damazego nauka Atanazego za pośrednictwem przebywajacego w Azymle Plotra Aleksandryjskiego, czy tez Euzebiusz zercelli.

Obok arianizmu Danazy p przesyłanym na Wschód wyznantu wiary potępla lakonicznie 1 bezimiennie równiez 1 inne herezje. Jest wśród nich potepiony modalizm sabelian/"nec redire in se nec minui, ut plerique blaspherant, sed semper manere, nec potentiae gradus quosdam ortusque tempora disparata"/, błędy Marcelego z Ancyry 1 Fotyna/ "nec prolativum, ut generationem el demas"/36 oraz rozrastajizca 81 coraz bardziej na Wschodzie herezja apolinaryzmu, odmaw iajaca Chrystusow 1 pernego czlowieczeństwa /"Eumdem redemptionis nostrae gratia processisse de virgine: ut perfectus homo pro perfocto, qui peccaverat homine nasceretur"/.

Oprós mypowiedz1 dogmatycznej, zachowany fragment listu Damazego zawiera warunki, jakie papiez usiłuje narzucié Wschodowi, jeśl1 ten chce posiadać "communto ecolesiastica" z Rzymem. Pierwazym

35 Ch.Pletri, loma Christiana, dz.cyt. 830; Po Damazym terminu tego odnośnie Ducha Sw. uzywax: Symbol Quicumque/"Spiritus Sanctus a Patre et Filio non factus nec creatus nec genitus, oed procedens" /, sw. Ambroky /De P1de, 3,13, PL 16,635/. Ambrosiaster /Quacetiones 121,41/.

36 Termin "prolativus" spotykany juz by u gnostykóiv 1 Ireneusza /Adversus haereses II, 13,8, SCh 294,124 : "Qui generationem prolativi hominum Verb1 transferunt"\%, potem zaé uzywał go Fotyn,
a po Darazym Asbrozy /De Plde, $4,4 /$. 
z nich jest bezdyskusyjne przyjęcie przez Wschód wiary Damazego: "Haec est, Pratres dilectissimi, fides nostra, quam quisque sequitur, noster est particeps... His nos communionen damus, qui nostram in omnibus sententian probant". Nie był to zwyczajny akt miłości 1 przyjaźni wobec Wschodu, ale, jak pisał P.Battifol, uporczywe wymuszanie przyjęcia wyłożonej przez siebie wiary ${ }^{37}$.

Druga grupa antyheretyckich wypowiedzi Damazego wiaże sie

z tzw. "Tomus Damasi", czyli listem synodu zwołanego w Rzymie w 377 r. 38 odpowiedzi na trzeci list biskupów Wschodu, informujzcyci - nasilającej sią działalności niekatolickich ugrupowán chrześcijańskich, a szczególnie zwolenników Éustacjusza z Sebasty, Apolinarego i Paulina39. Tragleznie przedstawiona sytuacja Kościołów wschod-

37 La siège apostolique, dz.cyt. 103; Ch.Pietri, Roma Christiana, $\mathrm{dz}$.cyt. 828 .

38 Od dawna trwa dyskusja odnośnie daty synodu rzymskiego, który jest autorem "Tomus Damasi", choć dziś większość autorów skłonna jest przyjmować datę 377 lub 388. C.H.Turner/Ecclesiae occ1dentalis monumenta iuris antiquissima, Oxford 1913, II, 283/ przyjmorvał datę $379 \mathrm{r} . ;$ E.Schwartz/Zur Kirchengeschichte des 4. Jahrhunderts, w: Gesammelte Schriften, Bd 4, Berlin 1960, 79-80/ proponował czas między końcem r. 377 a początkiem 378; P.Galtier/Le Tome de Damase. Date et origine, "Recherches de science religieuse" 26/1936/385-418,563-578/ wykluczając powyzsze daty proponował rok 382; P.P.Joannou /Die ostkirche und die Cathedra Petri, dz.cyt., 218 / proponuje początek r. 377; M.Simonetti /La crisi ariana nel IV secolo, Roma 1975, 432 / wskazuje na czas "około 377 roku"; V.Monachino/Il primato nella controversia ariana, dz.cyt., 52/ sugeruje koniec 377 r.; Ch.Pletri/iloma Christiana, dz.cyt., 381-840,873-880/ - rok 377 .

39 Por. Basilius, Epistola 263, PG 32, 976-981, tłun. Krzyzanlak 328-332: "Jeszcze raz za pośrednictwem umiłowanych braci pozdrawiany was 1 wzywamy, abyście nie ociagali się z nawiedzenien nas... a jeśsi to łaskę Bóg dobroci na czas inny zachowa, to przynajmniej pisujcie do nas ... lozliczne bovlem dla Kościoła nastały uciski 1 wielka jest nasza udreka ... Zuchwalstwo 1 bezwstyd herezji arian, jawnie juz zerwawszy z clakem Kościoła, iria " swym wasnym blędzie 1 wiele nam szkód sprawia ... Jest rzecza konleczna wypomnieć ich imiennie, tak lźbyście 1 wy sami poznali siejacych u nas zamęt, a naszym Kośclołom winę ich ukazali jaḱ oczywista ... I tak jednym z tych, którzy przysparzaja nam irielkiej zgryzoty jest Eustatios z Sebasty w Armenii Iniejszej. Siuchał on niegdyś wyisadów Ariusza ... został wyrzucony z grona biskupów ... Co przedstawił mu swlatobliny biskup Liberiusz, a na co on sam przyotik, nie wiesy, oprócz tego, ze przyntósł is st przywracajacy go do urzedowania i ze okazawszy go na synodzie - lizyale, przywrócony został na swe talejsce. Człowlek ów podkopu- 
nich skloniła zebranych na syuodzie biskupów pod przewodnictwem papieza do uzozenia i przeslania do Antiochii specjalnego listu dogmatycznego, który poprzez 24 anatemy i dołzczone do nich pozytywne ryjaśnienie potepia anonimowo lub imiennie ponicejskie herezje Wschodu. Cały ten dokument najbardziej dormatyczny ze wszystkich pisa Damazego, reasumujący ówczesną teologį́ rzymskiz, nazywany niekiedy "lkodeksem ortodoksji nicejskiej"40, sklada się wiøc z dwóch zasadniczjch cześci: zachowanego w dwóch fragmentach "Illud sane mirawur" I "Non nobis quidquam" pozytywnego listu dogmatycznego, "yjasniającego prawowierna nauke Kościoła ${ }^{41}$ oraz wykazu heretyckich tez potepionych 24 anatenami, opracovanego prawdopodobnie przy współudziale przebywajzcego w izymìe na wygnaniu Piotra $z$ Aleksandril, a nazywanego niekiedy damazjańskim wyznaniem wiary katolickiej ${ }^{43}$. To oficjalne kolektywne pismo Kościoła rzymskiego, skierowane tym razem juz nie do Paulina antiocheńskiego, ale kelecjusza $i$ jego synodu, zostalo w dwa lata później, jak już wspominaliśmy, podpisane przez 153 biskupów zgromadzonych na synodzie w Antiochil i przesłane z powrotem na rece Damazego. Z listy

je teraz te sanł wiare, dla której został przyjęty, znosi sie $z$ potepiajucymi orzeczenie współistotności i jest przywódea herezji pneumatomachów ... Drugim po nim siewcą zamętu jest Apolinary, który nic miejsze sprawia Kościołom utrapienia ... Pisma jego o weieleniu táci zamęt spowodowały wśród wspólnoty braterskiej, że odtąd niewielu tylko z tych, którzy się z nim spotkali, zachowało cechy dawnej pobożności ... Co zaś do Pallidna, to wy sami moglibyście się wypowiedzieć... skłania się $z$ przelonaniem $k u$ pogladom diarcelego ... A wiecie, bracia czcigocini, ze zagrozenie naszej nadziei tkwi właśnie w poglazaie harcelego; nie uznaje on bowiem, ze Syn iest co do hipostazy odrębny, ale głosi, ze znów wstapi on w Tego, z którego wyszedi, a ponadto Duchowi Polrzenicielowi tez nie przypisuje odrabnej hipostazy ... Domagany się od was, zebyście zajęli sio tu spriwa. Jeślibyścic bowien uznali za rzecz waściwa wystosować li:ty do wszysthich Kościolów Vischodu, przynajmniej to by sis osifulo, ze liznaczajacy doktryng wiary ... jeśliby chodeli obstalia dalej zucianale przy swoin nowinkarstwie, to hy odciclibysiay sia od nich".

40 Por. Ch.Pletri, doma Christiana, dz.cyt.,839.

41 il $13,352-354$.

$42 \mathrm{PL} 13,358-361$, Theodoretus, II.E.V, 11, GCS 19, 297-302. 
podpisów zachowało się jedynie 7 nazwisk, wóród których widnieja: Melecjusz z Antiochi1, Euzebiusz z Samosaty, Pelagiusz z Laudyk1, Zenon $z$ Tyru, Eulogiusz z Edessy, Bematiusz z Mallo 1 Diodor z Tarsu ${ }^{43}$. Przyjęcie wiary Damazego na Wschodzie oznaczało przykaczenie Melecjan 1 całego Wrchodu do communio ecclestastioa Kościoła rzymskiego oraz plerwsza oficjalna pozytywna reakeje Zachodu na wieloletnie wysiłki sw. Bazylego 44 .

Przejdźmy jednak do dogmatycznej wypowiedzi Damazego, zawartej we Pragmencie "Non nobis quidquam":

"Ut enim Nicaent concilit fidem inviolabilem per omnia retinentes, sine simulatione verborum aut sensu corrupto, nullo modo Spiritum Sanctum separamus; sed perfectum in omnibus virtute, honore, majestate, deltate, cum Patre conveneramur et Filio: itaque etiam plenitudinem Dol Verbi, non prolativi, sed nati, neque in Patre remanent1s, ut non sit, sed ex aeterno in aeternum subsistentem, perfectum, id est integrum hominem assumpsisoe et salvasse confidimus" 45 .

Latwo zauwazyó, ze zachowany eragment dołaczonego do anatem pozytywnego wykładu wyjaśnia ortodoksyjna naukę.Kościoła rzymskiego, skierowana przeciw trzem błędom: pneumatomachów, marcelian 1 apolinarystów, choć zaden z nich niè jest wymieniony imiennie. Widać w nim wiele podobieństwa terminologicznego z fragmentem dogmatyoznym juz przez nas omawianym "Ea gratia". Wykladajac ortodoksyjna nauke przeciw pneumatomachom, Damazy stosuje do Ducha Swietego te same terminy, które w Innym mlejecu odnosiz do Chrystusa: "perfectum in omnibus virtute, honore, majestate, deitate, cum Patre conveneramur et Filio"; chce przez to niewąpliwie wykluczyó wozelki cion subordynacjl Ducha Swį̨tego wobec pozostałych dwóch Osób Boskich,

43 Podpisy pod Pragmentem "Non nobis quidquam" PL 13, 353-354 wraz $z$ uwagq: "Similiter et al11 CXLVI Orientales episcopi eubscripserunt, quorum subscriptio in authenticum hodie in archivis Lomanae Ecclesiae tenetur".

44 Por. Basilius, Epistola 265, 3, PG 32, 989: "Biskupi Zachodu przyłaczyli was do nas. My otrzymaliśay od nich dekret wiary. zatrzymaliśmy go u siebie 1 poszlismy za jego ortodoksyni nauka". 
a równocześnie podkreślić pełna jego równość z Nimi. ¿ówność tę jeszcze wyraźniej podkreśli papieź w anatemach. Przeciw marcelianom uczacym, ze Bóg jest niepodzielna Monadą i jedna osobą, w kórej Słowo przebywa lmmanentnle tak, iz nle mozna mówlé o jakimkolwiek Jego rodzeniu lub tytule "Syna Bozegon"6. Damazy wraz z biskupami podkrésla, ze Słowo Boze nie pozostaje w ojcu, ale jest zrodzonym od wieków Synem Bozym: "etiam plenttudinem Dei Verbi, non prolativi, sed nat1, neque in Patre remanentis, ut non sit, sed ex aeterno in aeternum subsistentem". Powodem potępienta w tym miejscu marcelian byl fakt, ze do nich zaczęto na Wschodzie wliczaó równiez dotychczasowego nicejezyka Paulina z Antiochil, który faktycznie podzielal niektóre 1ch załozenia. Wreszcie przeciw apolinarystom głoszacym, ze Słowo Boze podczas wcielenia nie przybrało pełnego człowieka, a w zwiazu z tyn w dziele odkupienia nie uczestniczyło Jego pełne człowieczeństwo, stwierdzone jest lakonicznie ale dobitnie: "perrectum, id est integrum hominem assumpsisse et salvasse confidinus". Jeśl1 chodzi o damazjańskie anatemy na interesujący nas w tym miejscu temat, to sa one następujace ze wstępnym ich uzasadnieniem:

"Post concilium Nicaenum, quod in urbe Roma concilium congregatum est a catholicis episcopis, addiderunt de Sp1ritu Sancto. Et quia postea is error inolevit, ut quidam ore sacrilego auderent dicere Spiritum Sanctum esse per filium.

I. Anathematizamus eos, qui non tota 11 bertate proclamant, cum Patre et Filio unius potestatis esse atque substanti ie.

II. Anathematizamus quoque e0s, qui Sabelli sequuntur errorem, eundem dicentes Patrem esse, quem Filium.

III. Anathematizamus Arlum atque Eunomium, qui pari impietate, licet sermone dissimili Filium et Spiritum Sanctum asserunt esse creaturas.

IV. Anathemat1zamus Macedonianos, qui de Aril stirpe venientes non perfidiam mutavere, sed nomen.

v. Anathematizamus Photinum, qui Hebionis haeresim instaurans, Dominum Jesum Christum tantum ex Maria confitetur,

VIII Anathomatizamus eos, qui Verbum Filium Dei extensione, aut collectione, et a Patre separatum, Insubstantivum et Plnem habiturum esse contendunt.

46 Marcellus Ancyranus, Fragmenta 3-6 148 , gCS 14 /ed. E.Klostermann - G.Ch.Chanson, Berilin 1972/, 1861193 . 
X. Si quis non dixerit semper Filium et semper Spiritum Sanctum esse, anathema sit.

$X I$. Si quis non dixerit Filium natum de Patre, Id est de divina substantia ipsius, anathema sit.

XII. Si quis non dixerit Verbum Domini Filium De1 Deum, sicut Deum Patrem eius, et omia posse, et omnia nosso et Patri aequalem, anathema sit.

XVI. Si quis non dixerit Spiritum Sanctum de Patre esse vere ac proprie, sicut Filius de divina substantia et Deum veruin, anathema sit.

XVII. Si quis non dixerit omnia posse Spiritum Sanctum, omnia nosse, et ubique esse, sicut Filium et Patrem, anathema sit.

XVIII. Si quis dixerit Spiritum sanctum facturam aut per Filium factum, anathema sit.

XIX. Si quis non dixerit omnia per Filium et Spiritum Sanctum Patrem recisse, id est invisibilia, visibilia, anathema sit.

XX. Si quis non dixerit Patris et Filid et Spiritus Sancti unam divinitatem, potestatem, majestatem potentiam, unam gloriam, dominationem, unum regnum atque unam voluntatem et veritatem, anathema sit.

XXI. Si quis tres personas non dixerit veras Patris et Filil et Spiritus Sancti aequales, semper viventes, omnia continentes visibilia et invisibilia, omnia potentes, omnia Judicantes, omia vivificantes, omnia facientes, omnia quae sunt salvanda salvantes, anathema sit.

XXII. Si quis non dixerit adorandum Spiritum Sanctum ab omni creatura, sicut Filium et Patrem, anathema sit.

XXIII. Si quis de Patre et Filio bene senserit, de Spiritu autem Sancto non recte habuerit, haereticus est: quod omnes haeretici de Filio Del et Spiritu Sancto malo sentientes, in perfidia Judaeorum et gentilium inveniuntur.

XxIV. Quod si quis patiatur, Deum Patrem dicens, et Deum Filium eius, et Deum Spiritum Sanctum, Doos dici, et non Deum propter unan divinitatem et potentian, quam credimus esse et scimus Patris et Filil et Spiritus Sancti: Deum, subtrahens autem Filium; aut spiritum Sanctum, ita solum existimet esse Deum Patrem dici aut credi unum Deum: anathema sit. Nomen nomque deorum et angeils et sanctis omnibus a Deo est Impositum et donatua; do Patre autem et Fillo et Spiritu Sancto propter unam aequalem divinitatem, non nomen deorum, sed Del nobis ostenditur atque indicatur: ut credalius, quia in Patre et Filio et Spiritu sancto solum baptizanur, et non in archangelorum nominibus aut angelorum, quomodo haeretici aut Judae 1 aut ot 1 am gentiles demontos faciunt. Haec ergo et sulus chris- 
tianorum, ut credentes Trinitati, id est Patri et Filit et Spiritui Sancto, in ea veram solamque unaia divinitatem et potentiai ac majestatem et substantiam eamdem sine dubio credanus, ut aeterndun attingere mereanur ad vitam"47.

Jest to, Jak widać, pewnego rodzaju pierwszy chrześcijański syllabus, potępiajz̨oy głównie błędy antytrynitarne, ze szczególnym uwypukleniem równości Ducha Swiętego w stosunku do pozostałych Osób Boskich. Niektóre błędy, jak: arianizm, eunomianizm, macedonianizin, sabelianizm i fotynianizm, sa potepione imiennie, inne zaś, Jak marcelianizm 1 apolinaryzm, o ktorym powiemy nizej, tylko anonimowo. Wszystkie wyzej przytoczone anatemy moźna podzielic na dwie zasadnicze grupy: Jedna z nich potępla ogólnie błędy głoszace 1dentyczność wazystkich trzech 0s6́b Bosk1ch /an. 1,20,21,24/, druga zaś czyni to imiennie i detalicznie. Nie ma tu miejsca, by kazda z nich analizowaó dokładnie, ale trzeba podkreślić, że cały dokument poszuguje siz klasycznym teologlcznym słownictwem nicejskim 1 damazjańskim, opartyin na trynitarnej terminologil zachodniej 48 , w którym na czoło wysuwa się: "una substantia - una divinitas tres aequales; una potencia - majestas - gloria - divinitas". Jest tu równiez potępiony tryteizm/an. 24/, o który byl1 często oskarzani przez arian katolicy 49 .

Błedem byłoby twierdzenie, ze Damazy 1 zebrani z nim biskupi dokonali w powyzszych anatemach wielkiego dzleła teologicznego ${ }^{50}$, na miare traktatów lub pism polemicznych, ale nie to było ich zawarem: chcieli tylko wspólnie na synodzie podać w krótkich zdaniach, bez zbytniej dydaktyk1, krótk1 kodeks ortodoksji nicejskiej 377 roku, potępiajac w nim najgroźniejsze órczesne błędy religijne.

47 PL 13, 358-361.

18 Por. IIlarius, De Trinitate IX, 42; Eusebius Vercellensis, De Trinitate I, 1 ; III, 11; V, 40.

49. Por. Eusebius Vorcellensis, De Trinitate I, 16, CC 9, 7 ; Anbrosius, De fide V, 3,42; PL 16, 684-685; Ambrosiaster, Quaestiones 125, 23; Ileronyous, Epistola 15, 4;. Basilius, Epistolae 131 et 169.

50 Ch.Pletri, Roma Christiana, dz.cyt. 839. 
Miało to być pewnego rodzaju uzupełnienie Symbolu Nicejskiego, które mimo nievielkich rozmiarów, było ponariane lub potwierdzane jeszcze kilka razy pó́niej 51 oraz miało oddziaływá nawet na teologie wschodnia 52 .

\section{Apolinaryzm}

Druga groźna herezja trawiaca za pontyfikatu Damazego wochodnie chrześcijaństwo był apolinaryzm ${ }^{53}$. Jej twórca,bp Laodycel, Apolinary /310-390/, przez długi czas zarliwy obrońca Symbolu N1cejskiego, przyjaciel. św. Atanazego, Bazylego 1 nauczyciel św.Hieronima ${ }^{54}$, autor szeregu traktatów teologicznych biblijnych 1 apologetycznych, chcaco w swy nauczaniu fllozoficznie wytłumaczyé jedność Osoby Chrystusa w dwóch naturach, zaczaz głosic, ze podczas wcielenia słowo Boze zajęło w Chrystusie miejsce jego ludzkiej duszy. Początkowo odmawlal w ogóle Chrystusowi duszy ludzklej, pó́niej zaś 1dąc za platońskim rozróżnianiem w człowieku 3 elemen-

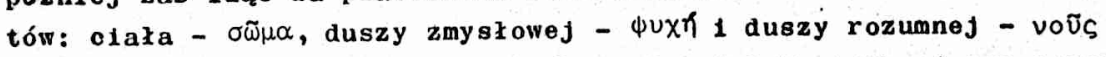
lub $\pi v \varepsilon \tilde{u} \mu \alpha$, uściślit swe poglądy 1 odmawial Mu tylko duszy rozumnej. Tego rodzaju zastapienie duszy rozumnej przez słowo Boze miato jego zdaniem zapernić jak najściślejsze połaozenie dwóch natur w Chrystusie. Swoja nauke uzasadnial między innymi zdaniem Ewangelil św.Jana, że "Słowo ciałem sie stało", zapominając, jak to pó́niej

51 Anatemy $i$ potepiente apolinaryzmu powtórzył w $382 \mathrm{r}$. synod·rzymsk1, por. Sozomenos, H. E. VII, 11, GCS 50,314.

52 Por. Sozomenos, H.E. $V_{i}, 25$, PG 67, Theodorus Mopsuestenus, Homélies Catéchótiques ix, 1 , ed. Tonneau-Devreesse, lomae 1949, pp. XVI et 215.

53 H.Lietzmann, Apollinaris von Laodicea und seine Schule, Tubingen 1904 /przedruk New York 1970/; G. Voisin, L'apollinarisme, Louvain 1904 ; C.A.daven, Apollinarism, An Essey on the Christolory of the Early Cinurch, Cambridge 1923; H. de lliedmattene La christologie d"Apollinilire de Laodicée. "Studia Patristica" 2/1957/ 208-234.

54 Por. korespondencje św. Bazylegro z Apolinarym, epistolae 361-364, PG 32, 1100-1108; II. de liedmatten, La correspondance entre Basile de Césarée et apolinaire de Laodicéo, "Journal of Theologlcal Studies" 8/1957/53-64; IIteronyus, Eplstola 84, 3, t tua. J.Czuj/Listy, t.1-3, Warszawa 1953/, t.2, 242-243: "Czesto slu- 
wyjaśniał Grzegorz z Nazjanzu, iz ewangelista posługiwał się tu kategorlarj umysłowyıi Hebrajczyków, dla których "ciało" oznaczało całego człowieka. Na polu filozoficznym rozumował logiczniej głoszac, ze dwle istoty doskonałe,pełne bóstwo 1 pełne człowieczeństwo, nie mogiz przy połzczeniu dać doskonałej jedności.

Głoszonego błędu biskupi ortodoksyjni długo nie dostrzegali. Jako pierwszy rozpoznał go na Wschodzie, jak sie zdaje św.Atanazy, który w liście synodalnym "Tomus ad Antiochenos" z $362 \mathrm{r}$. umieścił bezimienne zdanie, tz zbawiciel podczas wcielenia nie przyjął cla-

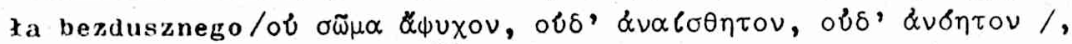
ale pełne człowleczeństivo ${ }^{55}$. W szerzeniu błędu w Antiochid wspomagał Apolinarego równiez wybitny zwolennik ortodoksji nicejskiej prezbiter 11 talis, który zorganizował nawet w ramach stronnictwa Paulina oddzielna wspólnotę apolinarystyczną. Gdy o błęnej nauce gloszones na Wschodzie powiadomiono papteza Damazego, ten wezwał do siebie w $374 \mathrm{r}$. Witalisa, polecając mu sie wytłumaczyć i złoźyć wyznante wary ${ }^{56}$; Witalis równiez chciał otrzymać uznanie papiéza dla stworzonej przez siebie wspólnoty. W jakiś blizej nieznany nam sposób zdołal on przekonać Damazego i jego synod o ortodoksyjności swojej wspólnoty, podpisaz przedstawione mu wyznanie wiary nicejsktej 1 zabrat w drodze powrotnej jakiś niezachowany list Damazego do bpa antiocheńsklego Paulina. Wkrótce jednak po jego wyjeździe, papioz blizej poinformowany, prawdopodobnie przez wracajacego z Antiochi1 Epifaniusza ${ }^{57}$ lub przebywającego tam Hieronima, poczut sie oszukany 58 wysłał jeszcze dwa listy do Paulina antiochéskiogo,

chaleu $w$ Antiochil Apolinarego 1 miakem dla niego uznanle, ale chociaz mnie ksztalciz w Piśmie św. nigdy nie przyjąłem od niego doginatu przewyiszajacego rozum. Już jego głowa okryła $81 \&$ siwizniz".

55 Athanas1us, Eplstola ad Antiochenos 7, PG 26,804.

56 F.Diekatap, Das Glaubensbekenntnis des apolinaristischen B1schofs Vitalis von Antiochien, "Theologische Quartalschrift" $80 / 1904 / 497-511$.

57 Por. Eplphanius, Ilaereses LXXVII, 22-38, GCS 37, 435-451.

58 dówlez Grzegorz z Nazjanzu skarzyl sie, ze zostal oszukany przez wracajicego z izymu Hitalisa, por. Epistola 102, PG 37, 196; POK 15, 147-150: "Aby mnie zas nie oskarzali, zem wyznanie wiary umflowineqo Vitaliusza, które tenze na żáanie błogosłarionego Damazelso biskupa izymu plsemie wydar, przedtem przyjmowal. a teras odrzuciar, 1 o tera krótko opowiea. Uni bow 
pierwszy, zaginiony przez prezbitera Petroniusza, a drugi, zachowany przez nieznanego nam blizej legata, w którya,zaniepokojony błędna gloszonz w Antioch11 chrystologiz, zobowiazywał go, zeby fitalis i jego wspólnota podjisali wobec niego wyznanie wiary nicejskiej wraz z dołazczonz klauzula, ze Chrystus we wcielentu przybrat pełnego cziowieka. Wieny $z$ innych źródeł, ze Witalis tego wymagania papłeskiego nie spełnił, ale w rok później został wyświęcony na apolinaxystycznego biskupa Antiochil. Zachowany Jednak list Damazego "Per filium" jest pierwszym zachodnim, choć bezimiennym, potępieniem apolinaryzmu. Oto interesujzcy nas fragment:

"Quapropter si supradictus filius meus Vitalis, et id qui cum eo sunt, tibi voluerint aggregari, primum debent in ea expositione fidei subscribere, quae apud Nicaeam pia Patrum voluntate firmata est. Deinde, quonian nemo potest futuris vulneribus adnibere medicinam, ea haeresis eradicanda est, quae postea in oriente dicitur pollulasse, id est, confitendus ipse sapientia, serwo filius dei humanum suscepisse corpus, animam, sensum, id est, integrum Adam, et, ut expressius dicam, totum veterem nostrum sine peocato hominem. Sicuti enim confitens eum humanum corpus suscepisse, non statim ei et humanas vitiorum adjungimus passiones: ita et dicentes eum suscepisse et hominis animain et sensum, non statim dicimus et cogitationum eum humanarum subjacuisse peccato. S1 qui auteo dixerit, Verbum pro humano sensu in Domini carne versatum, hunc catholica Ecćlesia anathematizat: necnon et eos, qui duos in Salvatore filios confitentur, id est, alium ante Inearnati nem, et alium post assumptionem carnis ex Virgine, et no, eumdem Dex filium et antea et postea confitentur"59.

swoich prawdziwyci uczniów $i$ wajemniczonych jak Manichejczycy o zagadnieniach teologieznych rozprawiajal... Przytalcuj t, że czlowiek w Chrystusie nie jest bez duszy, rozumu i umysłu, bez pełni, a le jako te dusze rozum i unys sano bústivo wprovadzaja, jalioby ono jedynie z cialen bylo spojone ... Cóz dziwnego, zem słowa Witaliusza talize za pobozne przyjąl ... Zdaje m1 sis, ze dlatego i sam Danazy lepiej pouczony, a zarazen dowiedziawszy siz, ze trwajl przy dawnya wykłalzie, wykluczyl 1ch z Koscioka, a pisemne wysnanie wiary obalił anatemą obruszaj fc sie na to onanienie, któreau ulegr w swej prostoduszności".

59 PL 13, 356-357. Kowentarz por. P.P.Joannou, Die Ostkirche und die Cathedra l'etri, dz.cyt. 186-191, 195-197; M.Sinonett1, Las crisi ariana, dz.cyt. 424-426. 
Widać z powyższego, że nauka Apollnarego, wyznawana 1 głoszona przez Witalisa, nazwana jest po raz pierwszy w liścle Damazego "herezją" rozwintęta na Wschodzle, która nalezy wykorzenić. Papiez nie wymienia jednak nazwiska jej twórcy, być może ze względu na duży autorytet zarliwego obrońcy wiary nicejskiej 1 sławę wielkiego teologa, Jakimi cleszył sie Apolinary, ale dostarcza tylko Paulinowi wyjaśntenia, które ma mu ułatwić rozpoznanie błędu. W wyjaśnientu tym Damazy ujawnia swe poglqdy antropologlczne, według których zgodnie z nauka Platona ozłowieczeństwo Chrystusa,podobnie Jak 1 Adama, składało s1ę z trzech elementów: corpus, anima،sensus, bez blizszego lch jednak objaéniania. Te trzy elewenty stanowia w Chrystusie pełnego człowieka, Jakim ongiś był Adam - "integrum Adam", z wyjatkien grzeohu. Tekst az dwukrotnie uprzedza przewidywany zarzut Apolinarego, zo Jeśliby Chrystus przyjąt pełnego człowieka, to muslałby róinlez przyjác jego słabości, jego skłonności do grzechu 1 narięt nośc1, stwierdzając bez żadnego uzasadintenia, jakie później podawali autorzy wczesnochrześcijańscy, że Chrystus przyjaz nasze clało bez tych słabości ${ }^{60}$.

Na zakoriczente swego dogmatycznego wykładu, papiez dołacza podwójnz anateme, wykl1najac tych, którzy ucza, ze "Słowo przebywaIo w clele Pana, zamiast ludzkiej duszy"/pro humano sensu/, oraz tych, "którzy przyjmuja w Zbawtcielu dwóch synów: jednogo przed woleleniem i druglego po przybraniu ciała z Dziowicy, a nte wyznaJa, ze był to ten sam Syn Bozy przed $i$ po wcieleniu". Nauka o dwóch synach przed 1 po woleleniu, głośna była w póńniejszym nestorianizmie, ale jako jeden z zasadniczych zarzutów wytykał ja katolikom, szczegúlnie orientacjl antiocheńskiej przyjmujacej w Chrystusie dwie pelne natury boska 1 ludzką, róvniez sam Apolinary ${ }^{61}$. Przed

60 Por. Gregorlus Nyssenus, Ant1rrhet1cus adversus Apollinarem 26, PG 45, 1180C: "Przyblerajic nasze grzechy na siebie, nie plami sie $1 \mathrm{ch}$ hieczystoscit, lecz w soble grzechy oczyszcza".

61 Pośw ladcza to zwalczajzcy Apolinarego Grzegorz z Nyssy, por. Antirrheticus 39, PG 45, 1212: "Jeślt z pełnya czlowiekjell zjednoozy sie pelny Bóg - mówi - to oczywiócle będa nle jednym,ale dwotna"; tanze 42, 1220: "Jeśl1 z człowiokiem potaczy s1ę Bóg, pelny z pelnym, to jost $1 \mathrm{ch}$ dróch, jeden Syn Boży z natury. a drugl 2 adopcji". 
tym zarzutem bronili s1 zdecydowanie katolicy, o ozym św1adcza wypowiedz1 współczesnych mu autorów zwalczajzcych jego naukę ${ }^{62}$. Powyzaze wypowiedzl Darnazego sq jeszoze bardzo ogólne, a pojęola przez niego uzywano/sensus, anima/ zbyt obszorne 1 trudno z nich wnioskować, czy chodzi tu o duszę zmysłowa czy rozumna, której włáñe Apolinary odmawiał Chrystusowi.

0 wiele wyraziniej przeciw epolinaryzmowi wypowiedziaz sie Damazy w $377 \mathrm{r}$. we wspomntanym juz wyzej synodyku "Tomus Damas1", zarówno w zachowanym Pragmencie "Illud sanen, Jak 1 wozaczonyoh anatemach:

"Asserunt enim dicere, Dominum ac Salvatorem nostrum ex Marla Virgine imperfectum, id est, sine sensu hominem suscep1sse. Heul quanta erit Arianorum in tall sensu vicinitas! Ill imperfoctam divinitatem in Dei f1110 dicunt, isti imperfectam humanitatem in hominis 11110 mentiuntur. Quod si utique imperfectus homo susceptus est, Imperfectum Dei munus est, imperfecta nostra salus; quia non est totus homo salvatus. Et ub1 erit 111ud diotum Domini: "Venit filius hominis salvare quod perierat totum"? 1d est, ot in anima et in corpore, in sensu atque In tota substantia suae naturae. S1 ergo totus homo perierat, necesse fuit ut ld quod perlerat, salvaretur. Si autem sine sensu salvatus est, Jam contra Evangelil fidem invenietur non totum quod perierat esse salvatum ... Nos autem, qui integros acperfectos salvatos nos scimus, secundum catholicae Eoclesiae professionem, perfectum Deum perfectum suscepisse hominem profitemur. Quapropter date operam, ut intelligentia sanae doctrinae etiam corum sensus salventur, qui adhuc sensum salvatum esse non credunt" 63 .

62 Por. Ambrosius, De Incarnatione 6,47, PL 16, 865: "Et 11108 condemnare debemus, qui non unum eundemque esse Filium Del dicunt, t allum esse, qui ex Doo natus sit, allum qui sit generatus de Virgino"; Gregorius Nazianzenus, Epistola I ad Cledonium, PG 37, 180A, POK 15,134: "Jeśl1 ktoś wrowadza dwóch synów, Jednego z Boga 0jca, a lruglego z matki, a nie tego samogo, to niech odpadnle 1 od tego usynowionia, które oblecano prawowlernym. Dwie to wprawdzle natury: Bog 1 czlowlek złozony z duszy 1 ciata, - ale synowlo nie dwaj and bogorle nie dwaj"; tenzo, Eplstola II ad Cledonium, PG 37, 196A, POK 15, 147: "Określ wszystkim co do mnio, zo Syna Bozego zrodzonogo z ojca, a potem zo śwletoj Dzlewioy Alaryl, w Jedno sprowadzata, 1 ndo dwóch synow nazyrail, lecz jednego 1 tego samego uw 10 lbium w niexozerwal nej boskósc1 1 czc1". Podobnie uczyz Atanazy. Eplcaniusz 1 inui. Zarzut Apolinarego wanowil późñoj pizociw katolikoin monorizyta Lutycises.

PL 13, 352-353. 


\section{Anatemy :}

VI. "Anathomatiramus 008 , qui duos f1l10s asserunt, unum ante saocula, of alterum post assumptionem carnis ex virgine".

VII. "Anathematizamus oos, yui pro howinis anima rationali et intoligibili, dicunt Del Verbum in humana carne versatum, cum ipse Filius git Verbum Dei, et non pro anima rationali ot intelligibili in suo corpore fuerit, sed nostram, ld est intelligibllem sine peceato animam susceperit atque calvaverit".

XIII. "SI quis dixer1t, quod In carno constitutus filius De1, cum esset in terra, in coel1s oum Patre non erat, anathema sit".

XIV. "SI qu1s dixerit, quod In passione orucis dolorem sustinebat Plilus Del Deus, et non caro cum anima, qua Induerat formam servi, quam sibl aoceperat, sicut ait Soriptura, anathema sit".

XV. "SI quis non dixerit, quod in carne, quam assumpsit, sedet ad dexteram Patris, in qua venturus est judicare vivos et mortuos, anatheina siti64.

Równiez wyzej przytoczonych tekstach, popartych autoryteten synodu, brak fest nadal imiennego potepienia Apolinarego. Plerwszy z nich, zaczerpniety z eragmentu "Illud sane", podobnie jak poprzednio, nadal jest bardzo ogólny w terminologil przy wyjaśnianiu zjednoczenla dwóch natur Chrystusie /sensus, totus homo, integer homo, hominis anima et sensus, Imperfecta humanitas/. Nieco więcej preoyzjl terminologlcznej przejawia Damazy w VII anatemio, gdzle jest zaznaczone, ze podczas wolelenta wedtug nauki Apolinarego słowo zajeto nie tyle dusze ludzka ogólo, ale dusze ludzka rozumna, która papiez w abundaoji słownej okresla "homints antwa rationalis et intelifgibilis.

Czymé nowym wowodzentu Damazego jest tu zastosowante $t z w$. argumentu soteriologioznego, domagajacogo ole priyjecia przez słowo wo wcieleniu pełnej natury ludzkiej wraz a dusza rozutana. Jesilby bowlem Chrystus nie posiadaz pelnego czkowluczerstwa, to nie mbgłby dokonac pelnogo odkuplenia. Poniewaz zaś perny czlowiek zgrzeszyl, konleczne byzo, zeby 1 jego zbawlelel mial pezni ludzka nature. W kllka lat pó́niej wyrazi to lapidarnie éw.Grzegorz z Nazjanzu: 
"Co nie zostato przybrane, nie jest uleczone; co zaś zjednoczone jest z Bogiem, to doznaje zbawienia"65. Wydaje sie, ze argumentu tego uży po raz pierwszy na Zachodzio św. Damazy, potem zaś stosowall go polentce antyapolinarystycznej powszcohnie zarówno autorzy zachodni ${ }^{66}$ jak 1 wschodni. Trzeba tu równiez podkrésllé, ze jest to pierwsze eynodilne uroczyste potepiente herezji Apolinarego, dokonane przes vamazego 67 .

Innym biçdem Apolinarego, zwlizanym z problemem duszy ludzkiej w Chrystisie, jest przyjmowany przez niego tzw. theopaschizm 68 , czy11 nauka, ze wyntku zjednoczenta. Słowa z niepełna natura ludzki, na krzyzu cierpiała 1 umierała natura boska. Bład ten znany juz w II wieku potępia XIV anatema "Tomus Damasi", chod nte mozna powledzleć, w jakim stopniu przyjmowaz go Apolinary ${ }^{69}$, a by on niewatpiliwie zarzucany Witalisow ${ }^{70}$.

Anatema wreszcie XIII potepia inny mało znany bład Biskupa Laodycei, który dopuszczał wątpliwośc, ze po wcleleniu mogłaby zaIstnieć możliwośc, iz Słowo Boze zwiqzane z c1ałem, mogłoby nie przebywać razem z ojcem w nlebie. Choclaz błąd ten zbijał Grzegorz z Nazjanzu i Grzegorz z Nyssy, to XIII anatema Damazego świadczy dobitnle o tyin, ze papiez znat nawet najtajniejeze zakamarki apolinaryzmu.

65 Por. Epistola $I$ ad Cledonium, PG 37, 184, POK 15, 138.

66 Por. Anbrosius, Epistola ad Sabinum, PL 16, 1196-1197: "Conf1teantur sicut in $D_{e i}$ forma nihil ei defuit divinae naturae et plentiudinis, sic in illa forma hominis nihil ol defulsso, quo imperfectus hono judicaretur, qui ideo venit, ut totum hominem salvum faceret; neque onim decebat, ut qui perfectum opus in alis consumaverat, hoc imperfectum in se esse pateretur; si enim aliquid ei defuit, non totum redemit; 81 non totum redemit, fefellit lgitur, qui dixit, ldoo se venisse, ut totum hominem salvum facoret".

67 Por. Sozomenos, H.E. VI, 25, PG 67, 1357-1360: Kaz1kowsk1 405: "Otoz jako pierwszy zrozumiat to Damazy biskup rzymski oraz Plotr biskup Aleksandril, ze herezja ta ogarnia szorokio kregl ludności 1 dlatego na zwołanym w lizymie gynodzle przeprowadzil uchwałe uznajica owa sekte za czynnik obcy powszochnemu Kośc1olow 1".

68 Ch.Pletri, Roma Chrigtlana, dz.oyt. 838.

69 G. Voisin, L'apollinarismo dz.cyt. 310-311.

70 Tauze, 347. 
Doplero jestenta 377 r., wilka miesiegcy po przestaniu na Wsohód "Tomus Damasi", zan1m Plotr aleksandryjsk1 powrócli na swa otoliog/po 2 XI 377/. papiez potęp1z Imiennie Apolinarego na synodzle rzymskim, nazywajac go wprost heretykier wraz z jego uczniem bpem Beryttos Tymoteuszem, którego złozyz z urzędu. Ten ostatni jednak nie od razu ustapiz, chob jego usuntęcla domagal1 s1e duchowni Beryttos ${ }^{71}$. W odpowiedzi na tę prośbe Damazy skierowal na pocz. 380 r. l1st do bpów Wechodu 1 kleru Beryttos oznajmiając o owym imiennym poteppientu Tymoteusza 1 Apolinarego 1 zachęajac, by nie utrzymyw11 z nim stosunków. Było to pewnego rodzaju społnienie zadań biskupów Wschodu, domagajqoyoh ale wyłaczenia z Koścloła trzech heretyków, a wáród nich Apolinarego ${ }^{72}$. A oto wypowiedź Damazego:

"Solatis velim, eratres, nos Timotheum 11lum profanum, ApolInaris haeretiol disoipulum, oum impio suo dogmate jampridem abdloasse; ot ob eam causam credimus, rellquias eius nihil In posterum moment1 habituras. Quod 81 antiquus 1110 serpens, semel atque iterum lotus, ad suam 1 psius poenam augendam revixerit, et extra Ecclesiam ejectus, nonnullos etiamnum fideles suis mortiferis venenis, quibus eos tentare aggreditur, ad exitium trahere non cesset, vos hanc ejus astutiam velut pestem quamdam declinato, et recordamini sedulo tum ridel ab apostolis traditae, tum huius vel maxime quae ost a sanotis Patribus in concilio Nicaeno soriptis prodita: Inque a gradum Irme defigentes, immobiles perstate; ... Jam non semel formulam edidimus, ut qui se christianum proPiteatur, lllud teneat, quod ab apostolis traditum est; ... Nam Christus Filius Dei, Dominus noster, generi humano per passionem suam plenissimam salutem reddidit, ut totum hominem peccatis implicatum ab omni peccato liberaret. Hunc 81 quis aut imperfectam humanitatem, aut imperfectam divinitatem habuisso dixerit, spiritu diaboli completus, so fillum gehonnae ostendit... /Timotheus/ abdicatus est una cum magistro suo Apolínare, qui item in die judicil debitas poenas ot supplicia persolvet. Quod si ilie, qui verain spem In Christum una oum P1del confessione mutarit, velut spem quandam salutis retinens, al 108 quosdam, gui sunt loviores, ad suam perducat sentontiamil 3 .

11 Por. Epintola Damasi ad op1soopos Orientales, PL 13,371: "Itaque quid est, cur abdioutionem Tinotiel a me rursus requiratis, qiil etlam hio judiolo sodis apostolicue, Potro quoque episeopo Alexan.

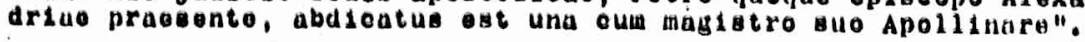

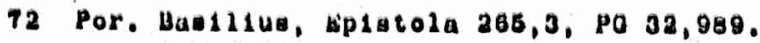

73 PL 13, 370-371. 
List rozpoczety barazo uroczyście, z powolywanien się na rolę $i$ autorytet Stolicy Apostolskiej, przyjuje później, jak widać z powyzszogo pragnentu, w przeciwieństwie do innych zachowanych pism Damazego, cinarakter pewnego rodzaju inwektywy, stosowanej nierzadko w antyheretyckiej polemice wczesnochrześcijańskiej ${ }^{74}$. Heretyk nazwany tu jest: "antiquus serpens", "spiritu diaboli completus", "filius gehennae", jego zas nauka: "mortifera venena", "astut1a", "pestis", "impium dosma". Papiez zachęca do pozostania przy wierze przckazanej przez apostołów, potwiordzonej przez ofców na Soborze nicejskiti. Jest tu wreszcie uzyty, aczkolwiek ogólnie, argument soteriologiczny, przypominajicy, ze Chrystus we weieleniu musiał przybrać pelną nature ludzka, bo inaczej nie dokonałby peznego zbavienia.

Tak oto wyględa przedstawiona schematycznie, w oparciu o zachowane pisma apologetyczna,działalność papieźa Damazego. Dalszą inicjatywę w zwalczaniu herezji przejał cesarz Teodozjusz/379-395/, który killona a'stail prawnym doprowadził do lch formalnej likwidacj1. Najpierw 27 II $380 \mathrm{r}$. wydał $w$ Tesalonice dekret nakazujacy wszystkim mieszkańcom jego państwa przyjęcie obowlazzkowe wiary papieza Damazego 1 Plotra aleksandryjskiego ${ }^{75}$. W rok później 10 I 381 r. zakazał wszystkim przeciwnikom wiary nicejskiej jakiegokolwiek kultu w Meście, ich zaś świąynie polecil odlać katolikom ${ }^{76}$. Wreszcie $\$ 383$ r.zwolal do Konstantynopola biskupów wszystkich sekt i wyznań, zaż̨dal od nich pisemnych wyznań wlary, na podstawie których wszystkich przeciwników Symbolu Nicejskiego skazal na wygnanie ${ }^{77}$.

$$
\text { Ks.Stanisław Longosz - Lublin }
$$

\section{DE PAPA DAMASO FIDEI OITHODOXAE PIOPUGNaTOdE}

\section{/ Argumentum /}

Hac in dissertiuncula ratione 1600 anniversaril Damas1 Romae Episcopi mortis praeparata exponitur, quomodo llle papa orthodoxam fidem ab erroribus, praesertim haoresi Arianorum necnon Apollinaristarum defendebat.

74 Por. S.Longos\%, Inwektywa clarześc1jariska, SWl 530-537; tonze, Inwektywa Lucyferiusza z Cilaris, .TK 19/1972/ z.4, 181-194.

75 Codex Theodosianus XVI 1,2 .

76 Tauze,XVI 5,6 .

77 Socrates, H.E.V, 10, PG 67,584-585. 